\title{
CRISIS MANAGEMENT
}

\author{
VÁLSÁGKEZELÉS
}

ZÓLYOMI Zsolt

(ORCID: 0000-0002-2800-1430)

\section{zszolyomi1@gmail.com}

\begin{abstract}
The security professionals are always talking about Emergency Plan, Emergency Preparedness, Emergency Response, Crisis Management, Crisis Management Plan, Business Continuity Management, Business Continuity Plan. etc. That is a question which comes to my mind do we know exactly what these phrases meanings are? My experiences show, usually we have different interpretations on the above mentioned expressions. Briefly we need to have an Emergency Plan to provide our Emergency Preparedness and to be able to take our Emergency Responses in case of a real Emergency situation. If we were able to eliminate the Emergency situation the problem has been solved. If we had no success the Emergency can be develop a crisis situation which we need to manage by the Crisis Management Plan. As we are over the crisis we need to adopt our Business Continuity Plan to be able to manage our continuous operation or production. The aim of this study to provide a useful tool or set up for security leaders on Crisis Management which is a clear security task and not as like Emergency Preparedness which is related to safety organization as Business Continuity is connected to each business functions.
\end{abstract}

Key words: security, emergency, plan, crisis, business continuity,

\begin{abstract}
Absztrakt
Biztonsági szakemberek gyakran használják a következó kifejezéseket, hogy vészhelyzeti terv, vészhelyzeti készenlét, vészhelyzeti válaszlépések, krízis menedzsment, üzlet folytonossági terv, stb. Egy kérdés fogalmazódott meg bennem, vajon biztosan tudjuk, hogy mit takarnak ezek a fogalmak? Tapasztalataim azt mutatják, hogy általában különböző értelmezéseket társítunk ezen meghatározásokhoz. Röviden, szükségünk van egy vészhelyzeti tervre, hogy biztosítani tudjuk a vészhelyzeti készenlétünket és megfelelö válaszlépéseket tudjunk tenni egy valós vészhelyzet esetében. Amennyiben képesek voltunk megszüntetni a vészhelyzetet, akkor megoldottuk a problémát, ha nem értünk el sikert, akkor a vészhelyzet krizishelyzetté válhat, amit a krízismenedzsment tervünk segítségével kell megszüntetnünk. Ahogy sikerült a krízist felszámolnunk, akkor lesz szükségünk az üzletfolytonossági tervben foglaltakra, hogy minél elöbb vissza tudjunk állni a normális operációra, termelésre. A tanulmány célja, hogy biztositson egy használható eljárást, illetve folyamatot a biztonsági vezetök részére, amely segítségükre lehet a krízis menedzsment feladatainál, minthogy ez tisztán biztonsági feladat, ellenben, az inkább a munkavédelemhez tartozó vészhelyzeti feladatokkal és az üzlet minden szegmensét érintö üzletfolytonossági tervvel. .
\end{abstract}

Kulcsszavak: biztonság, vészhelyzet, terv, krízis, üzletfolytonosság. 


\section{INTRODUCTION}

The security professionals are always talking about Emergency Plan, Emergency Preparedness, Emergency Response, Crisis Management, Crisis Management Plan, Business Continuity Management, Business Continuity Plan. etc. That is a question which comes to my mind do we know exactly what these phrases meanings are? My experiences show, usually we have different interpretations on the above mentioned expressions. Briefly we need to have an Emergency Plan to provide our Emergency Preparedness and to be able to take our Emergency Responses in case of a real Emergency situation. If we were able to eliminate the Emergency situation the problem has been solved. If we had no success the Emergency can be develop a crisis situation which we need to manage by the Crisis Management Plan. As we are over the crisis we need to adopt our Business Continuity Plan to be able to manage our continuous operation or production. The aim of this study to provide a useful tool or set up for security leaders on Crisis Management which is a clear security task and not as like Emergency Preparedness which is related to safety organization as Business Continuity is connected to each business functions.

We can take an example according to my view. We suppose there is a burning trash can in an office area. It is an Emergency situation. If everything goes well somebody take a fire extinguisher and estinguish that small fire. It was a clear Emergency situation and it is over. If the things are not going well that burning trash can does not noticed in time, that fire can be bigger and can block Emergency exits, so people can get into life threatening situations. The impact of that Crisis situation can be huge. People, assets, environment and reputation can be damaged heavily. It is one of the most important process what each company, business organization, etc. must to cover.

When the Crisis is over have to begin with Business Continuity process to go back to normal operation as soon as possible.

Need to establish complete Emergency, Crisis and Business Continuity Management with Plans, Procedures and Management. If those complete procedures implemented, the Company Management educated and procedures are tested and excercised, they can be sure they Emergency and Crisis Preparedness are on adequate level.

If they get an Emergency or Crisis event the damages will be much less because they are well prepared.

\section{GENERAL RULES}

The Company Crisis Management System is designated to mitigate the impact of a crisis involving Company operations or the safety and welfare of the people and on the environment. The system establishes a crisis preparedness and response model and outlines strategies and procedures for dealing with a crisis. [1, p.34-35.] [2, p.47-52.] The Company Crisis Management System:

- Describes Company Crisis Preparedness \& Response Model

- Provides guidelines for Crisis management plans within Company

- Establishes roles and responsibilities of Company senior management and supporting staff in responding to a crisis.

The Crisis Management System is very much linked to Emergency Response System. The Emergency Response System is focused on immediate tactical response to a certain emergency situation where the Crisis Management System deals with strategic issues \& responses. [3, p.18.] 


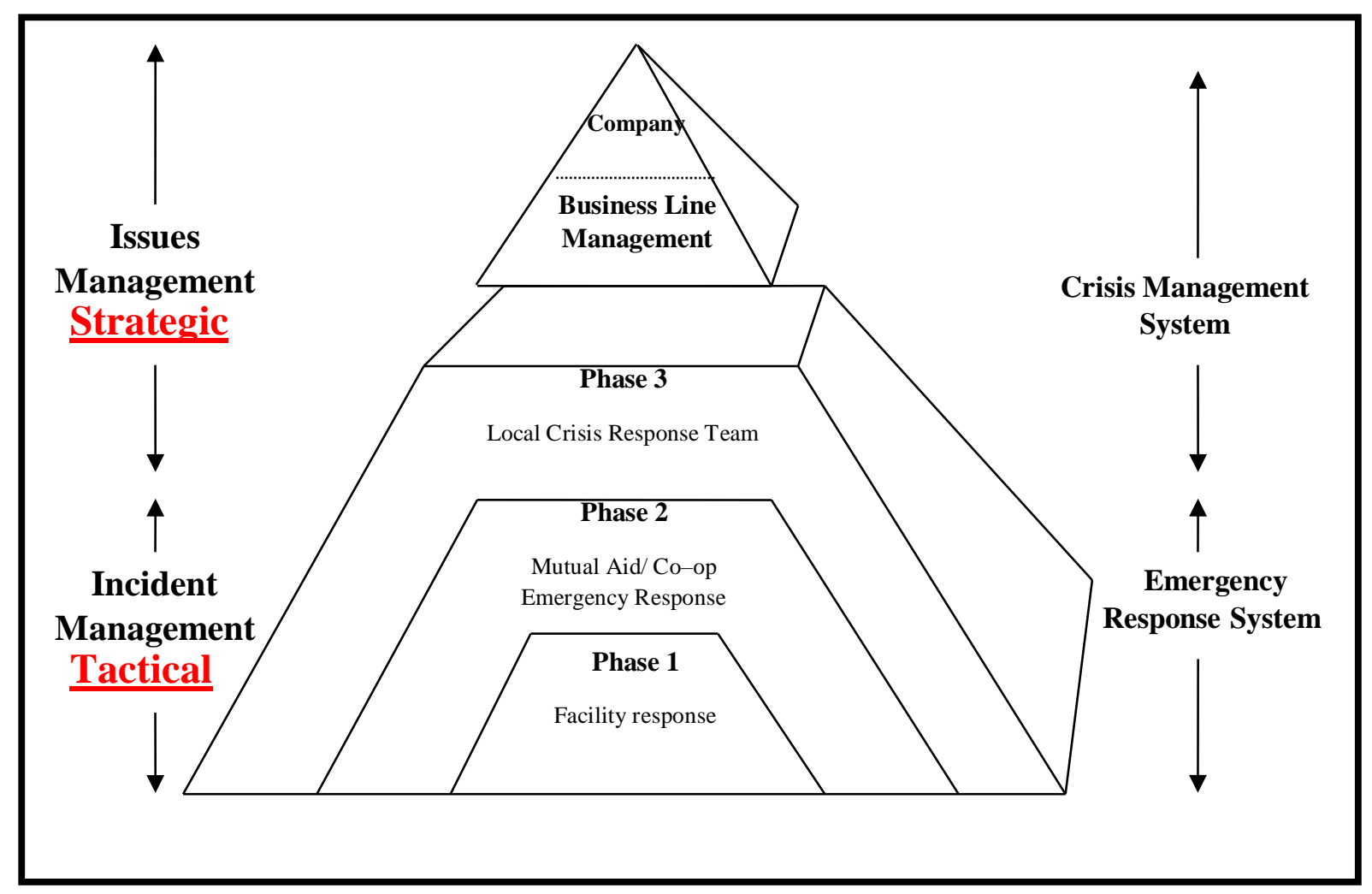

1. Illustration Illustration of Crisis Management System (made by the author)

\section{EMERGENCY/ CRISIS RESPONSE MODEL}

The Company Emergency/ Crisis Response Model provides Business Units, country managers, and site managers with guidelines for mounting an appropriate field and issues management response. These guidelines are based on levels of incident severity. [4, p.60-68.] [5, p.70-78.]

The levels are:

- Phase 1 - Incident is small and under control and may involve a response from Company managed resources - Emergency Response System

- Phase 2 - Incident is large but under control and involves mutual aid cooperative response, possibly national media coverage - Emergency Response System/ Crisis Management

- Phase 3-Incident is large and is not under control and requires Emergency Response System/ Crisis Management

Three levels of severity define response modalities. Mitigating factors and critical issues affect the response level. The levels rating system is based upon the severity of emergencies. Level of response needed for an emergency.

Phase 1 response is from a local facility, etc., and has the following characteristics:

- Emergency is small and under control

- Emergency occurs on Company or customer property

- Facility has capability of managing the emergency

- Local equipment (owned by Company or contractor) is sufficient to manage the emergency

- Local media and or public attention is focused on the emergency 
- Response is by site Local Emergency Response Team

Example: A site accident such as small gas release or contaminating spill quickly contained and controlled.

Phase 2 response involves mutual aid or cooperative response and has the following characteristics:

- Emergency is large but under control

- Emergency occurs on non-Company or customer property

- Facility has the capability of managing emergency

- Mutual aid co-operatives are activated

- Contractor equipment is needed to aid in managing the emergency

- National media attention focused on emergency

- Response is by site, Local, or Crisis Management Team

Example: A gas release or spill resulting in contamination and injuries.

Phase 3 response requires a Local Crisis Management Team and has the following characteristics:

- Emergency is large and is not under control

- Significant government presence is focused on emergency

- Environment is impacted by emergency

- Human welfare is impacted by emergency

- Local, national, or international commerce is disrupted

- Partial or full Local Crisis Management Team is activated

- International media attention is focused on emergency

Example: A gas release, fire or spill with long term impact.

\section{Crisis preparedness \& response strategy}

Company Crisis Management System establish a structured and systematic process for responding to events or situations that pose a threat to the safety and welfare of the people and the environment which arise from Company operations. Company Crisis Management System addresses the issues management and communications components of a three-part strategy required for an effective response. It does not attempt to provide guidance relative to the incident management or field aspects of a response. Company three-part crisis preparedness and response strategy should include:

- Incident Management or tactical response implemented by the field unit/ emergency response team supported by Local Crisis Management Team.

- Issues Management or the strategic response implemented at the appropriate country level supported by Company Headquarters (HQ) Crisis Management Team. Issues management can be categorized to include the following:

- People

- Protect human welfare

- Environment

- Protect the environment

- Assets

- Communicate with financial community

- Assess impact on current and future business

- Commit funds as appropriate 
- Meeting needs of customers and business partners

- Reputation

- Acknowledging responsibility as appropriate

- Anticipate and address public perception

- Mobilize senior executives

- Communicates with employees, governments, media and shareholders

Communicating a clear and consistent message that underscores Company's concern and commitment is vital to a successful response. The message is not just intended for media but also applies to external communication between Company's employees and customers, partners, vendors, contractors, governmental authorities, and non-governmental organizations. This message has four key elements:

- Concern

- Working together with government

- Taking action

- Preparedness

\section{Philosophy, purpose and relationship between plans}

The Company business unit affected by the incident has the primary responsibility to implement a response unless explicitly determined otherwise by Company HQ level Management. The incident response management is at the lowest appropriate level. The Company HQ Crisis Management Team (Company HQ CMT) provides the structure and process for response activities to identify and address strategic issues, as well as, to support the field response. The process is flexible, allowing the headquarter team to be staffed appropriately to meet the requirements of the situation. [6, p.11-12.] The purpose of the Company HQ CMT is to:

- Establish communications with the field

- Support the field/ business unit needs

- Identify strategic issues

- Assess potential impact of the incident

- Communicate with senior management

- Manage the issues at the lowest appropriate level

The following basic structure shows the relationship between plans for incident response, consistent with Crisis Preparedness \& Response Model. 


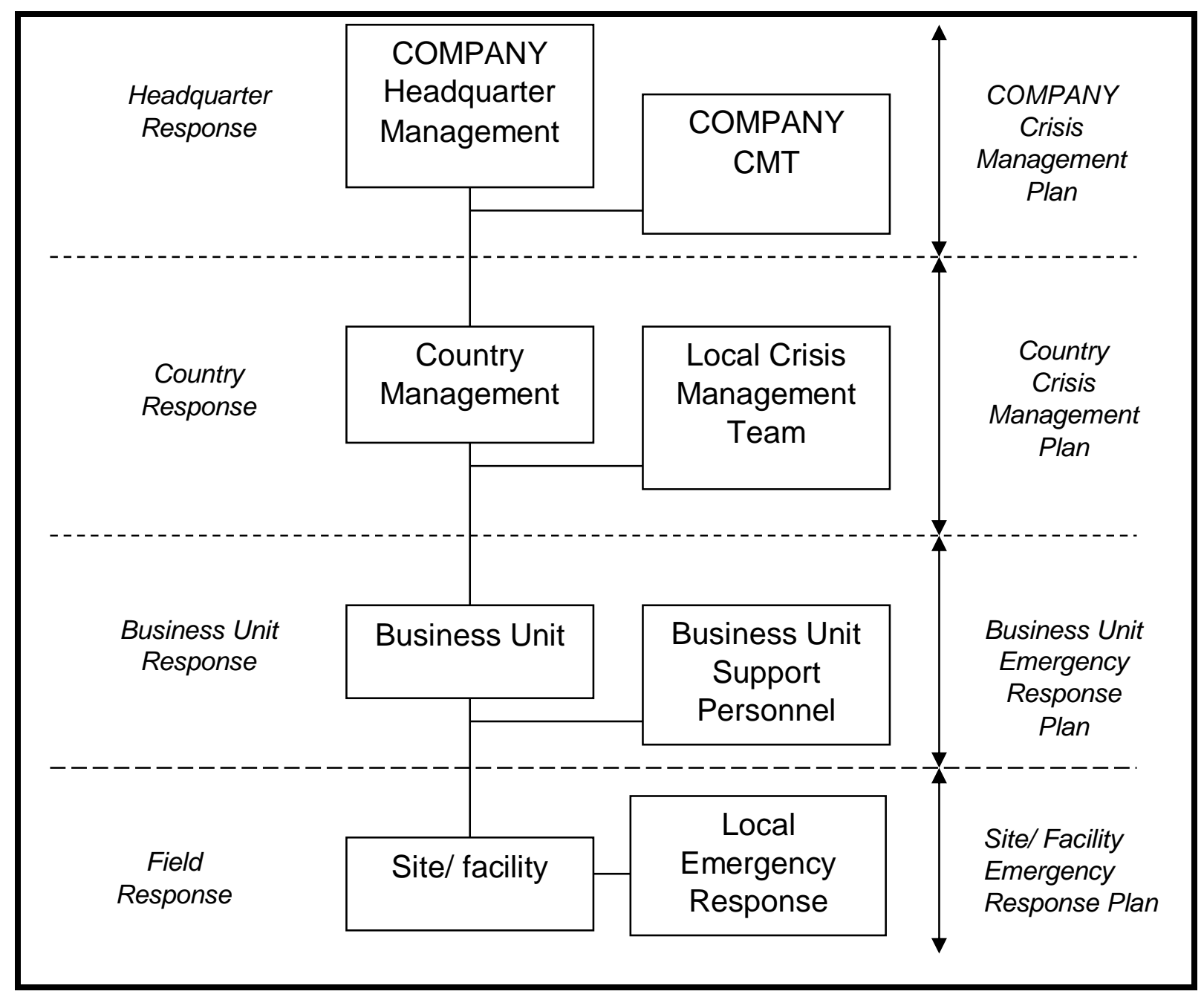

2. Illustration Crisis preparadness and response model (made by the author)

The Country process addresses issues raised by government, regulators, media which operate within a country and have expectations of a senior group response from within that country. The Local Crisis Management Team handles strategies and allows the Emergency Response Team (ERT) the space and opportunity to deal with the tactical emergency response. When to notify? [7, p.28-31.]

Emergencies or incidents that require screening and communication include most Health, Safety and Environment emergencies where the Company's products or premises are involved. This includes emergencies related to production, construction, transport, marketing, etc.

Emergencies may include:

- Major process failures: explosions, fires, material spills, and releases

- Criminal or terror attacks

- Utility supply disruptions that have a significant operational impact

- Product contamination, liability

- Natural disasters (floods, earthquakes etc.) or manmade catastrophes

\section{Soft activating criteria}

Critical Issues:

- Managers and personnel need to be aware of how to answer to the following questions can affect incident outcome.

- Is Company responsible for this incident? 
- Has Company successfully assessed potential exposure from the incident?

- Have appropriate notifications been made?

- Does Company understand the needs and pressures of governing regulatory agencies?

- Can the field organization or a third party manage the response?

- Are documentation procedures in place to protect Company?

- Should a senior executive visit the incident site?

Communication issues: [8, p.98-107.]

- Managers and personnel also need to consider the following:

- What are Company's communication strategies?

- Is Company managing potential long term effects of the incident?

- Is Company monitoring public perception of the incident?

- Is Company monitoring stakeholders of the incident?

- What public officials will have an interest in the incident?

- Has Company taken steps to ensure rapid communication of facts?

\section{Severity assessment guidelines}

The incident severity assessment establishes notification requirements and quickly communicates the relative significance of an incident to Company HQ Management. An emergency can change rapidly, and accurately assessing the incident is important. Making an assessment requires consideration of subjective as well as objective facts regarding the nature of the incident. The quality of the incident severity assessment generally improves, as more information about the incident becomes known. Early information may be misleading or incorrect, and it is important to not underestimate the incident severity. The assessment process requires current, factual knowledge about incident. Consistent and accurate assessments are necessary for emergency response plan to function properly.

Company established the method for assessing incident severity that considers four primary exposure factors for the incident. These are:

- People (public health/ injury)

- Environment

- Liabilities (financial, assets)

- Reputation

A severity level of 1,2,3,4 or 5 should be assigned to each of these primary exposure factors where 1 is the least severe and 5 is the most severe exposure. The overall incident severity is the determined as the highest level assigned to any one of the four primary exposure factors.

Assessing the severity is a judgment process based on available facts. The following guidelines are provided for assessing incident severity:

- The severity assessment should be based on known factual information. Since many smaller incidents have potential to become larger, it is important to maintain discipline in assessing severity. The only area in which potential occurrence is considered is in the area of reputation. The reason potential is considered in this area are that news media reacts quickly to reports of visible incidents of involved response organization.

- The severity level of an incident may change during the course of the event as new information becomes known or the situation changes. Thus, periodic reviews of the severity level should be made during the course of the incident and revisions made as appropriate. 
- The purpose of the severity assessment is to forecast the potential impact of the incident on Company.

\section{Notification and reporting}

Timely communication within Company organizations and, where appropriate, to external authorities or groups, is critical for effective incident management. Communications cover numerous informational needs during an emergency, including the: $[9, \mathrm{p} .70$.

- Technical aspects of the emergency

- Information needed for Company HQ management

- Interfaces with external audiences, regulatory agencies, government authorities, nongovernmental organizations, and the public

The flow of such information is structured in a tiered system. The greater the incident severity and Company HQ response, the higher the level of Company HQ management involved in the process.

When to notify

Emergencies or incidents that require screening/ communicating as specified by regulation include most security, safety, health, and environmental incidents where any of Company's product is involved. This includes emergencies that occur in production, manufacturing, distribution, and retail use of our products. Emergencies also include incidents where safety, health and environment may be exposed to external elements such as:

- Hostage, terrorist acts, vandalism, sabotage

- Utility supply disruptions

- Product contamination, liability

- Floods or other natural disasters, manmade catastrophes

- Major process failures: explosions, fires, material spills and releases

- Bomb threats

Who to notify

Multi channels path for Company country level to notify Company HQ level:

- For the purpose of emergency communications, the country level business line manager notifies the Company HQ level Business line executive. Company country level management should maintain up-to-date telephone list to allow emergency communication with appropriate contact executive on a 7 day/week, 24 hour/day basis.

- For the purpose of emergency communications, Company country level corporate communication should notify Company HQ level Corporate Communication contact.

- For the purpose of emergency communications, Company country level Health Safety Environment coordinator should notify Company HQ HSE manager.

- For the purpose of emergency communications, Company country level security manager should notify Company HQ security manager.

\section{RULES OF ENGAGEMENT FOR ALL CRISIS RESPONSE INCIDENTS}

In order to minimize impact of an emergency involving Company, the organization will be prepared to act as follows:

- If Company is responsible for incident, Company will respond rapidly and effectively to mitigate the event. 
- If the responsibility for the incident is unclear, Company crisis preparedness and response resources will be prepared to act.

- If Company is not responsible for the incident, Company may provide technical or advisory assistance to the response effort (with appropriate legal safeguards).

Company crisis preparedness and response resources may be mobilized when the following circumstances arise to ensure rapid response to an emergency. The country management authorizes the emergency response:

- To protect the viability and safety of any Company facility

- At the order of government, or under legal duty

- At the request of a government when adequate cost recovery and liability protection exist

- As a member of an industry mutual aid/ cooperative when adequate cost recovery and liability protection exist

Company HQ must be consulted for approval before responding to the following circumstances:

- At the request of a government when adequate cost recovery and liability protection exist

- As a member of an industry mutual aid/ cooperative when adequate cost recovery and liability protection exist

- As a voluntary response to a local community emergency

Note: response to any life threatening situations should not be delayed in situations where the guidelines require informing or consultation with headquarter management. If an operating unit is contracted to third party any emergency related to such operation is the primary responsibility of the involved third party.

\section{ROLES AND RESPONSIBILITIES}

\section{Overview}

At the time of an emergency, the site affected by the incident has primary responsibility to initiate the response. This includes immediate, site operations undertaken in response to the incident, external interactions necessary to manage the incident's business impacts, and overall communication activities associated with the response. This continues to be the case unless Company HQ, in consultation with the affected site, explicitly determines otherwise.

\section{Convening the Local Crisis Management Team}

After determining that the event has the potential to become an emergency, affected business line manager may choose to convene the Local CMT. The affected business line manager or other designated will chair the Local CMT. Other members will be drawn in to support emergency.

The Local CMT, when convened, would normally:

- Notify appropriate HQ business line management. Note: security, communication and HSE also required to notify HQ.

- Maintain communications with HQ business line management by keeping them informed on the status of the emergency and response plans.

- Evaluate the emergency, overall response actions, and potential impact on business unit operations. 
- Review and confirm the adequacy of the resources and management organization in place to deal with the situation.

- Cooperate with both country and HQ controllers to assess and facilitate changes to guidelines and budget or other authority in light of necessary response actions.

- Make decisions regarding senior executive presence on-scene.

- Facilitate inter-functional coordination and cooperative efforts.

- Determine potential business unit response needs including meetings with senior government officials.

- Review and concur on external communications with significant legal or business implications to business unit.

- Establish how and to what degree other business unit personnel are to be updated on the emergency and response activities.

\section{Membership}

If the Local CMT is activated to provide support for emergency related activities, the key positions will come from affected business unit. The Local CMT typically would comprise of representatives of communications, human resources, security, law, finance and HSE. In addition, resource personnel of individual(s) who possesses specific operational expertise (potentially from the impacted business unit) may be included in the Local CMT to enhance the group's effectiveness.

Crisis Management Team Objectives:

- Determine principal impact, as well as, potential impact of an emergency on Company as a whole with regard to:

- Human welfare and the environment

- Position and responsibility

- Reputation and Company image

- Operability and business continuity

- Liability and loss potential

- Gather and analyze available information and determine strategies for managing the emergency including both internal and external implication

- Ensure information associated with the incident is promptly considered and communicated, and those decisions regarding escalation and de-escalation are addressed

- Support site response organization

- Prepare briefing material for CMT review and potential use by the Company

- Facilitate other business unit or functional support and assistance

- Ensure that lessons learned from incidents are properly documented and shared and that opportunities for improvement are appropriately captured

\section{CRISIS MANAGEMENT TEAM ROLES}

\section{CMT leader}

- Represents Business group most impacted by emergency

- Activates CMT and assumes leadership position

- Determines priority of issues facing the business and formulates a strategy for managing them

- Responsible for briefing CMT and updating as appropriate

- Accountable for overall activity of the CMT 
- Identifies other business potentially impacted and calls for Impacted Business Advisor.

\section{Deputy CMT leader}

- Assists in decisions regarding staffing of Emergency Management Centre

- Manages the day-to-day operations of the Emergency Management Centre

- Assumes CMT leadership role in absence of the CMT Leader

- Collaborates with CMT leader and CMT process facilitator in:

- Identifying issues and action items to send to senior management

- Providing field response support

- Developing briefings for senior management

\section{Impacted business advisors}

- Advise leader of impacts and sensitivities of other businesses within Company

- Provide input to CMT and assist in developing strategies

\section{Crisis management process facilitator}

- Activates and ensures adequate support staffing of Crisis Management Centre upon direction from CMT leader

- Accountable for ensuring operational Crisis Management Centre

- Provides focus to the overall decision making process and guidance in the deliberation process to identify and process critical strategic issues.

- Coordinates Crisis Management Team agendas/ briefings

- Assist CMT in development of emerging issues, scenario planning, development of senior management briefings, etc.

\section{Site liaison}

- Advises CMT on:

- The repercussions of an incident on the business and subsequent effect on the unit and/ or impacted business

- Coordinates implementation of any strategic decisions affecting the site experiencing the incident

- Establishes contact with affected site key personnel to ensure that appropriate and factual information is being received by the CMT (e.g., periodic situation reports from the incident site).

Note: Business experience and familiarity with the affected business unit operations and organization is essential for this position.

\section{Country Manager}

- Coordinates external relation (media, government, communities, general public)

- Advises on national statutory obligations

- Communicates the status and the effects of the crisis to employees within the Company

- Consult with the CMT leader and communication on media, government and public relations activities and strategies

- Consult with law and elsewhere as necessary on Company statutory obligations in terms of the incident 
- Ensures that the Company employees are effectively kept up-to-date with the crisis status and effects

- Facilitates cross-business resource utilization to optimize the response.

\section{Communication}

- Advise on:

The current or likely effects of the emergency on Company image and reputation with regard to the public, government and its stakeholders

- Effective external communications with all affected parties

- Consistency of internal communication being promulgated across Company group companies

- In the event of a major incident communication will activate their emergency response plan and become the member of CMT.

- Propose overall communication plan

- Collect/ consolidate outside inquiries

- Prepare/ coordinate responses/ statements

- Coordinate response approval process

- Disseminate approved responses

- Monitor public reaction

\section{Legal}

- Advise CMT Leader of legal implications or alternative response strategies and actions

- Consult with and advise site/ country legal personnel

- Obtain essential facts relating to legal aspects of the incident

- Review legal aspects of reports/releases

- Flag potential key legal issues to CMT Leader

- Maintain personal log

- Develop legal response strategy

- Review sensitive communications and advise, and after-action report drafts

\section{Security}

- Maintain liaison with appropriate national law enforcement and security officials

- Provide advice and recommendations on employee security and welfare, security of assets, and investigative matters

- Determine security action plan

- Recommend need for additional security support

- Clarify and verify information regarding the incident

- Maintain CAS (Controlled Access System)

- Consolidate information from outside security services

- Develop proposed investigative/protective strategies

- Coordinate investigative/ protective strategies with law representatives

\section{Human Resources}

- Provide advice on policy issues and coordinate with appropriate management to secure approval for exceptions if needed

- Work with emergency response group personnel to consider specialized HR issues (i.e., labour relations, benefits, legal compliance, policies)

- Coordinate with communication on employee/ contractor communications issues 
- Maintain personnel records

\section{Finance}

- Establish, coordinate and supervise claims investigation and claims handling services as required

- Establish claims office and guidelines for consideration of claims

- Oversee claim payments, as appropriate

- Advise CMT Leader of applicable insurance coverage/ terms and claims status

- Provide necessary notification to insurers and other parties/ entities as warranted

- Provide contracting advice relative to insurance

\section{Technical support}

- Technical Support needs are unique to each incident. The CMT Leader/ CM Facilitator is responsible for calling out technical resources as needed, which could include, but not limited to the following groups:

- Engineering \& Research

- Information Technology

- Procurement

- Technical experts from affected Business Line

\section{Health safety \& environment}

- HSE support needs are unique to each incident. The CMT Leader/ CM Facilitator is responsible for calling out HSE support as needed, which could include but not limited to the following:

- Safety Expert

- Medical Expert

- Industrial Hygiene Expert

\section{Functional representation}

- Generally required where the impact of the emergency is across business units or where there are limited personnel from particular function in country

- Provide advice on issues relating to their business unit (separate to site liaison)

- Assist the CMT in understanding the impacts and sensitivities of the function

- Advise CMT on the repercussions of an incident on the business

- Coordinate implementation of any strategic decisions affecting the impacted function. 


\section{CRISIS MANAGEMENT STRUCTURE}

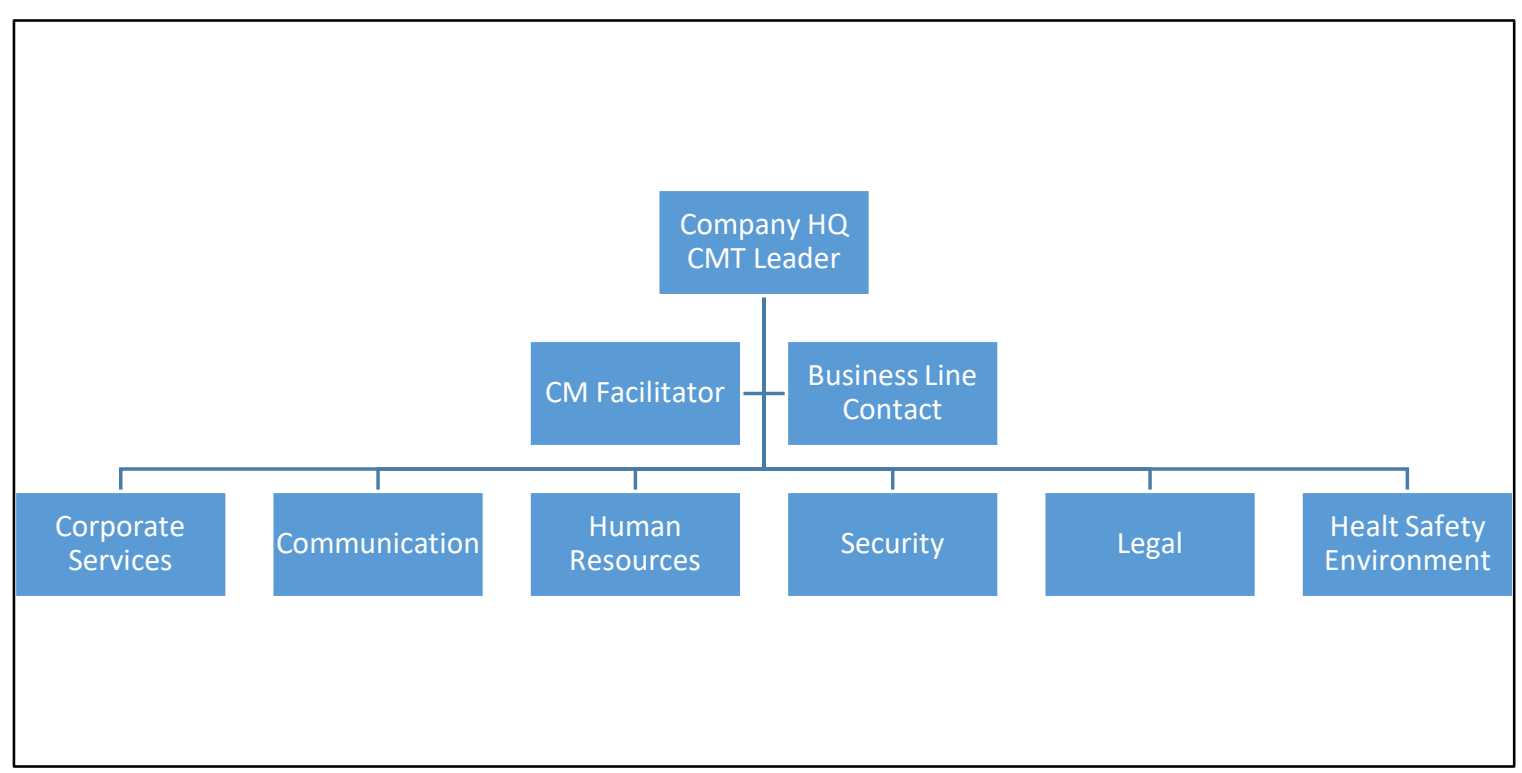

3. Illustration Structure of Company HQ level Crisis Management (made by the author)

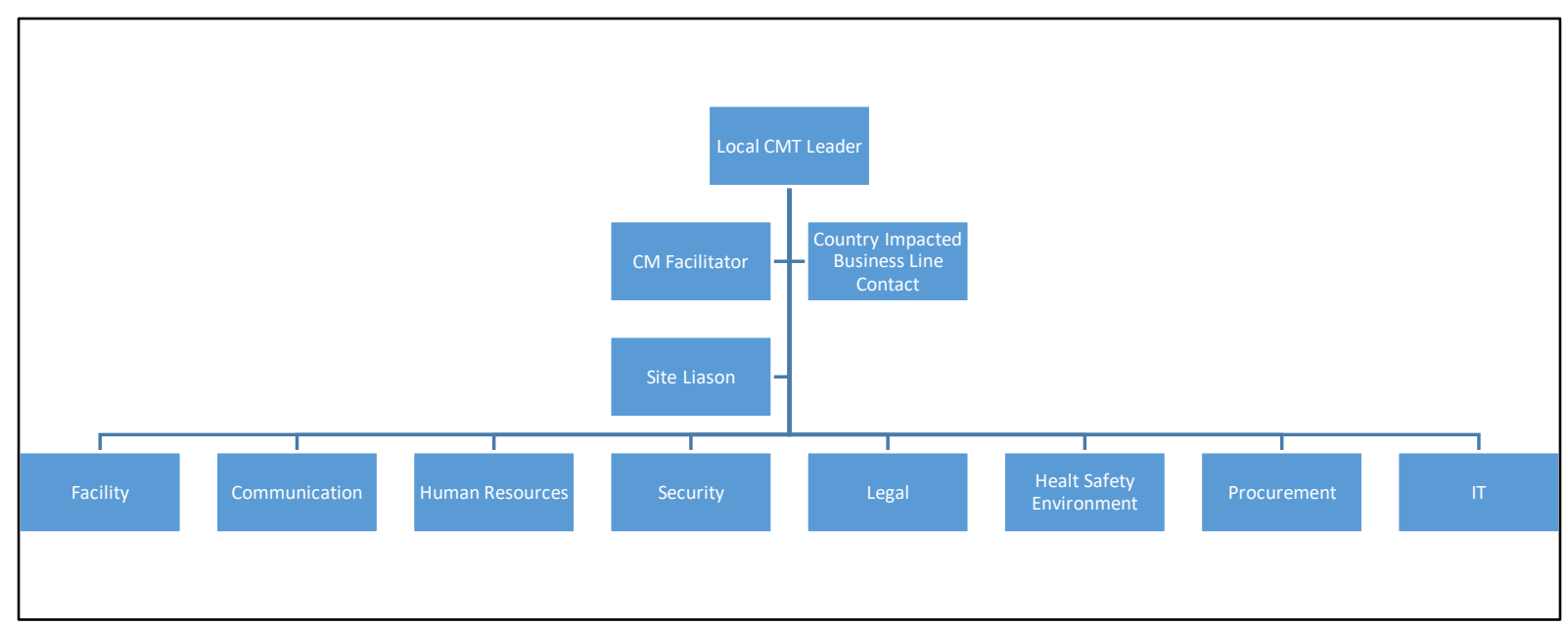

4. Illustration Structure of Local Crisis Management (made by the author) 


\section{CRISIS MANAGEMENT PROCESS}

The following is the process for the Crisis Management Team meeting. These activities are designated to provide a structure for meeting the objectives of the CM Team meetings.

\section{Initial team meeting activities}

Accomplish these activities during the initial CM Team meeting:

- Provide update of incident status

- Identify incident owner

- Identify Crisis Management Team and Team Leader

- Review crisis response management process

- Assure clarity of roles for team members

- Identify team objectives

- Document high-level team concerns

\section{Initial team meeting process}

Complete the following steps for the initial team meeting:

\begin{tabular}{|l|l|}
\hline Task & Action \\
\hline $\mathbf{1}$ & Assemble team in Crisis Management Centre \\
\hline $\mathbf{2}$ & Crisis Management Leader briefs team \\
\hline $\mathbf{3}$ & Set 3 to 4 objectives \\
\hline $\mathbf{4}$ & Team members brainstorm issues \\
\hline $\mathbf{5}$ & Discuss issues relevant to objectives \\
\hline $\mathbf{6}$ & Prioritize issues and develop action items \\
\hline $\mathbf{7}$ & Gather and process information and work action items \\
\hline $\mathbf{8}$ & Define worst case scenario \\
\hline $\mathbf{9}$ & Formulate and refresh strategy each day \\
\hline
\end{tabular}

1.Table Initial team meating process (made by the editor)

\section{Guidelines for brainstorming issues}

Use these guidelines when brainstorming during CMT meetings

- Keep discussions high-level

- Brainstorm key issues

- Consolidate and prioritize issues

- Employ the Issue management process

- Work critical priority issues

- Segregate issues from Action Plan

- Park issues not related to objectives

\section{Work process when convened}

When the CMT is convened, the work process below is used. 


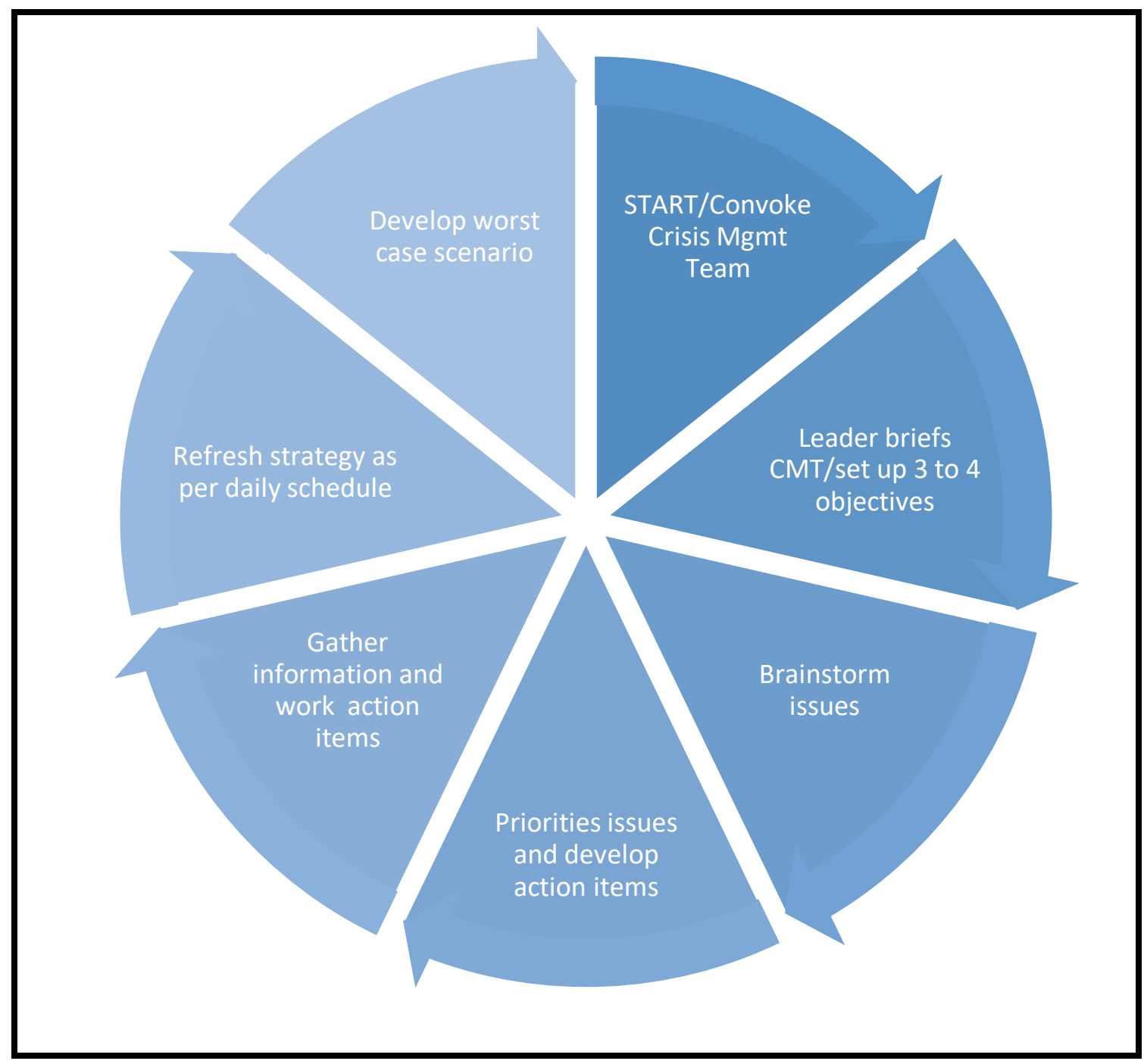

5. Illustration Structure of Local Crisis Management (made by the author)

\section{CRISIS MANAGEMENT CENTRE}

Communication between Local CM team and Company HQ must be vital to an effective crisis response. Designated facilities are therefore required for the personnel to effectively fill the roles that have been defined in this plan. Company has established a Crisis Management Centre and Media Centre. Responsibility for maintaining Crisis Management Centre lies with Security and Corporate Communications has responsibility to maintain Media Centre. A fully functional facility has to be established in each country and at the Company HQ. The centre is used for duration of crisis response activities related to an incident.

\section{TRAINING REQUIREMENTS}

\section{General}

Employees require training to ensure safe and environmentally sound operations, to protect their own health of themselves, and to comply with laws and regulations. Effective training of employees involved in the crisis response process ensures our crisis preparedness. This is true for those who respond to the incident scene and those who fill the roles established in all Company Crisis/ Emergency preparedness and response plans. 
The training should at minimum include:

\begin{tabular}{|l|l|}
\hline CORE TRAINING PROGRAM & AUDIENCE \\
\hline Process or system training & $\begin{array}{l}\text { Emergency responders and those filling } \\
\text { roles established in the plans (CMT } \\
\text { members) }\end{array}$ \\
\hline General regulatory compliance awareness & Same as above \\
\hline $\begin{array}{l}\text { CMT drill participation. This requirement } \\
\text { may be satisfied by active involvement in } \\
\text { response to an actual incident }\end{array}$ & Same as above \\
\hline
\end{tabular}

2.Table Training programs (made by the auditor)

Initial training requirements may lead to same level of refresher training to ensure crisis preparedness. The frequency of refresher training should be established by owning organization's crisis response system and should be based upon the risks associated with its operations.

\section{Training responsibilities}

Each individual involved in the CMT and their line management is responsible for ensuring that training is completed for the identified crisis response roles.

\section{CRISIS RESPONSE DRILLS REQUIREMENTS [10, p.51-56.]}

\section{Type of drills}

- Table top exercises

In these exercises Crisis Management process is reviewed with CMT and there are facilitated discussions on how Company would respond on a scenario. Generally, the outside resources do not participate. These exercises are coordinated by security leaders.

- Simulation exercises (with or without equipment deployment)

These exercises mobilize staff or resources and activate the Crisis Management Centre and the CMT. Outside resources might participate in the simulations. These exercises are planned and coordinated by owning organization. The scope of such exercises can include simulation in multiple locations. The scope could also include deployment of Emergency Response Teams and equipment to test and practice their procedures and also to practice the interface with Company HQ level CMT.

\section{Drill planning [11, p.18-20.]}

Each exercise will be planned. The plan will identify the members of the planning team, the purpose of the exercise, the scale of exercise, the management involvement, the duration of exercise, the outside resources involvement, and the plan for review of results. The purpose of drill includes one or more of the following: validate Crisis preparedness and response plans, test readiness, train participants, and identify areas for improvement in plans and procedures. The plan for drill will be included in the exercise's assessment documentation. 


\section{Drill assessment}

All drills will be assessed to determine whether drill objectives have been met and to document the areas for improvement in the Crisis/ Emergency response system. The results of the assessment will be documented and reviewed by appropriate management.

\section{Drill schedules}

During the fourth quarter of each year, each business line will issue a schedule for drills for following year and will submit these to Security.

\section{COMMUNICATIONS}

\section{Internal communication guidelines}

When an incident occurs with Company implications, communications should ensure that employees receive appropriate information regarding the crisis. Just as with external communications, internal communications should convey care and concern for the situation and provide factual information.

\section{Implementation}

Company public statements regarding a crisis situation will be provided by country communications to the Company HQ Communications simultaneously with public release. The Company HQ communications should determine what further distribution to business operation and site employees is needed.

\section{External communication guidelines}

An integral part of Company's crisis response is the timely development of appropriate and effective external communications which convey care and concern for the situation and provide relevant factual information. The incident description and Company response must be conveyed as appropriate, not only to those directly affected, but also to all relevant government authorities and to the general public, via the media, whose perception of the event will be shaped by media events.

\section{Implementation}

When a crisis activates the Country Emergency Preparedness \& Response Plan, the in- country communications is convened in support of the CMT. The communication has the role and responsibility that ensure effective management of crisis communications in the following functions, it is expected that the country communications is organized to ensure coverage of these functions as required by the nature and severity of the crisis.

- Employee communications

- Media communications

- Customer/ suppliers communications

- General public/ community relations

- Government relations

- Trade associations (as appropriate)

- Shareholder communications (as appropriate)

In case of a significant emergency (level 4,5) for which the Company HQ p CMT is activated to provide the focal point for crisis related activities, it may be decided that Company HQ 
communications will assume overall responsibility for managing internal and external communications. The decision to activate the Company HQ CMT and assume overall responsibility for communications is made by Company HQ Executive Director. This decision will be communicated immediately to the respective Company HQ. Country communications will retain management responsibility for the duration of the incident.

For (level 4,5) emergencies for which Company HQ communications assumes responsibility for overall management of internal and external communications, Company HQ communications will prepare a Company HQ Communications Plan. This plan will include the Corporation's crisis communications objectives and strategies as related to key Company's audiences.

\section{SUMMARY}

'Many organizations think they have good crisis plans in place when, in fact, their enterprise preparedness programs are fragmented into different silos ${ }^{(\mathrm{x})}$ [isolate (one system, process, department, etc.) from others] with poor coordination, communication and collaboration.'[12, p. 76.] Each crisis plan is useful as the process is behind that. Need to have a plan, need to have educated team members and need to be exercised at least annually. The crisis preparedness is the key of the successful crisis management in any kind of crisis situations.

\section{REFERENCES}

[1] GOODCHILD, Joan: At the Ready - Emergency Response. CSO, ISSN 1540-90X 2009/11. p.34-35.

[2] SPADANUTA, Laura: Planning for Disaster. Security Management, ISSN 0145-9406, 2012/03. p.47-52

[3] GOODCHILD, Joan: New Cybersecurity Standards for N. American Power System. CSO, 2009/06. p.18.

[4] BARHAM, John: After the Flood. Security Management, 2008/11. p.60-68.

[5] MURPHY, Jack. J: Rising to the Challenge. Security Management, 2008/11. p.70-78,

[6] BRENNER, Bill: A Wake-up call for Emergency Planners. CSO, 2009/06. p.11-12.

[7] How Security Should Handle Pickets \& Strikes, MANLEY, Anthony's book: CSO, 2010/08. p.28-31. Excerpted by permission from Security Manager's Guide to Disasters to CSO, CRC Press, 2009. www.crcpress.com

[8] POGAR, Joel A.: Keep Communications in a Crisis. Security Management, 2007/06. p.98-107.

[9] LOKEY, William M: Don't let Plan Be the Disaster. Security Management, 2009/06. p.70.

[10] ELLIOTT, Robert: State of Readiness. Security Management, 2006/12. p.51-56.

[11] SPADANUTA, Laura: How to prepare for Drill. Security Management, 2010/09. p.1820.

[12] LITTLEJOHN, Robert F.: Don't Silo Crisis Solutions, Security Management, 2009/06, p. 76. 